\title{
Mitogen-Activated Protein Kinase Kinase Kinase Kinase 1
}

National Cancer Institute

\section{Source}

National Cancer Institute. Mitogen-Activated Protein Kinase Kinase Kinase Kinase 1. NCI

Thesaurus. Code C150080.

Mitogen-activated protein kinase kinase kinase kinase 1 (833 aa, $91 \mathrm{kDa}$ ) is encoded by the human MAP4K1 gene. This protein plays a role in the modulation of serine/threonine kinase-dependent signaling pathways. 